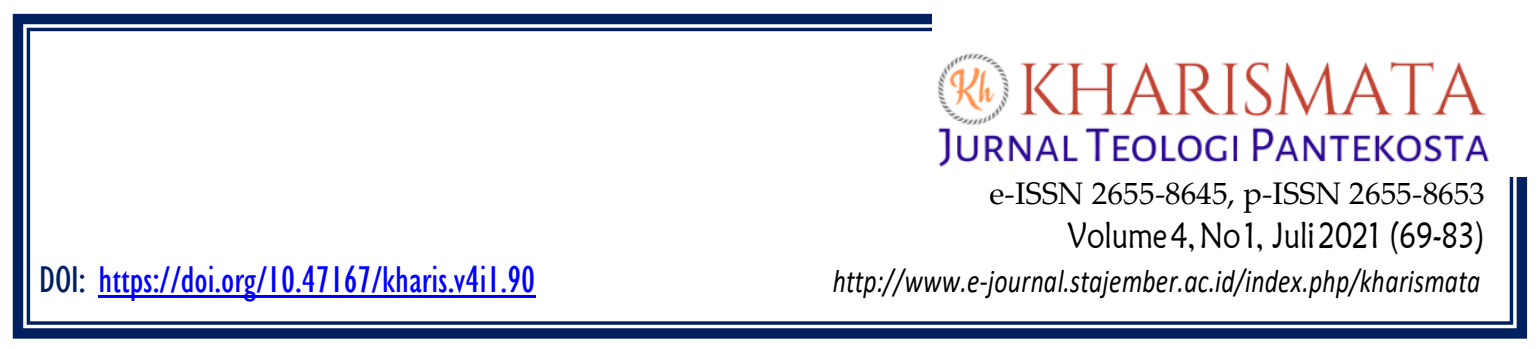

\title{
Menanamkan Kerukunan di tengah Masyarakat Multikultural melalui Pendidikan Kristiani
}

\author{
Paulus Purwoto1, Reni Triposa 2 , Yusak Sigit Prabowo ${ }^{3}$ \\ 1,3Sekolah Tinggi Teologi Torsina, Karanganyar \\ 2Sekolah Tinggi Teologi Sangkakala, Salatiga \\ *Correspondence: pauluspurwoto022@gmail.com
}

\begin{abstract}
The harmony that has been torn so far as a result of the ethnicity, religion, race, and inter-group relations (SARA) conflict threatens the diversity of the nation. Even the horizontal conflicts that have occurred so far have caused wounds and trauma for all communities. This study aims to provide understanding for pastors, teachers, and believers so that they can play a role in the scope of Christian religious education to be able to emphasize the value of harmony in a multicultural society. Through a descriptive qualitative method with a literature study approach, the researcher tries to answer the research problem by searching for literature sources, both books, and journals, that correlate with the research problem. The conclusion of this study is the first by understanding the value of wisdom and the importance of maintaining harmony in society, Christians can contribute to actualizing the meaning of harmony, both internally and amid religious communities within Indonesia. Second, Christian religious education can be used as a media in instilling and actualizing the value of harmony in a biblical perspective in a multicultural society. The three people believe that they can provide education in the community and family so that they are expected to become actors of tolerance in a pluralistic society.
\end{abstract}

Keywords: Christian religious education; dialogue; multicultural; tolerance

Abstrak. Kerukunan yang terkoyak selama ini akibat adanya konflik SARA mengancam kemajemukan bangsa. Bahkan konflik horizontal yang terjadi selama ini menimbulkan luka dan trauma bagi semua masyarakat. Penelitian ini bertujuan untuk memberikan pengertian bagi gembala, guru dan orang percaya sehingga dapat berperan dalam lingkup pendidikan agama Kristen untuk dapat menanankan nilai kerukunan di tengah masyarakat multikultural. Melalui metode kualitatif deskritif dengan pendekatan studi pustaka, penulis berusaha untuk menjawab permasalahan yang terdapat dalam penelitian dengan mencari kajian dari berbagai sumber literatur baik buku maupun jurnal yang berkorelasi dengan masalah penelitian. Kesimpulan penelitian ini adalah yang pertama dengan memahami nilai kearifan dan pentingnya menjaga kerukunan dalam bermasyarakat, orang Kristen dapat berkonribusi dalam mengaktualisasikan makna kerukunan, baik dalam lingkup intern maupun antarumat beragama di Indonesia. Kedua, Pendidikan Agama Kristen dapat dipakai sebagai media dalam menanamkan dan mengaktualisasi nilai kerukunan dalam persepektif Alkitabiah di tengah masyarakat multikultural. Ketiga orang percaya dapat memberikan edukasi dalam komunitas maupun keluarga sehingga diharapkan dapat menjadi pelaku toleransi dalam masyarakat majemuk.

Kata kunci: dialog; multikultural; pendidikan agama Kristen; toleransi 


\section{PENDAHULUAN}

Bangsa Indonesia dikenal dengan bangsa yang demokratis dan menghargai berbagai pendapat, mempunyai semangat untuk membangun toleransi, bercirikan budaya sopan santun, memiliki jiwa gotong royong di antara anak bangsa dalam naungan kebersamaan demi tercapainya jiwa kerukunan yang tinggi. Hal tersebut membentuk sebuah tatanan masyarakat yang hidup damai sejahtera dalam kemajemukan yang terdiri dari berbagai perbedaan suku, logat bahasa, budaya yang multikultural, serta ditengah perbedaan keyakinan atau agama.

Salah satu yang perlu diwaspadai di tengah kemajemukan dalam multikultural adalah potensi disintegrasi, atau konflik horizontal di tengah kehidupan masyarakat. ${ }^{1}$ Oleh karena itu, dalam membangun nilai kerukunan maka diperlukan dialog dan interaksi yang aktif serta efektif antara berbagai pihak supaya dapat memberikan sinergi dalam membangun keutuhan bangsa. Dengan tujuan supaya sesama umat beragama, maupun antarumat beragama dapat mewujudkan masyarakat yang hidup dalam toleransi sehingga dapat berdampak bagi terwujudnya masyarakat yang harmonis. Paulus Purwoto, et al, dalam penelitian terdahulu menjelaskan bahwa dialog komparasi dalam kepercayaan atau keagamaan merupakan salah satu cara yang ampuh dalam melaksanakan pemberitaan Injil, di tengah-tengah kehidupan masyarakat sosial yang mejemuk. ${ }^{2}$ Dengan dialog akan mempersempit kesalahpahaman, menekan terjadinya problem lintas agama dan lintas kultur. Namun demikian masih terdapat fakta yang memprihatinkan diantaranya: Adanya sikap golongan tertentu dari masyarakat dengan tindakan dan perlakuan yang refresentatif dan anarkis terhadap kepercayaan dan agama. Serta sikap tidak terpuji seperti menghina dan melecehkan pemimpin umat dari agama atau kepercayaan tertentu. Bahkan adanya tindakan diluar nalar dalam provokasi kekerasan yang berlatar belakang SARA berdampak bagi konflik dan perusakan tempat Ibadah yang terus naik. ${ }^{3}$

Pertikaian horizontal antarkelompok, etnis, dan agama di lingkungan masyarakat saat ini masih cukup terbuka ${ }^{4}$, seperti yang terjadi di berbagai daerah di wilayah Indonesia. ${ }^{5}$ Juga adanya sikap dan perilaku yang tidak menyenangkan, seperti: sikap tidak mengayomi, kurangnya keadialan perlakuan aparat yang menimbulkan kesenjangan terhadap masyarakat tertentu, adanya kecemburuan terhadap tingkat pendapatan atau kecemburuan ekonomi, perbedaan pendapat yang kurang mengedepan-

${ }^{1}$ yonatan Alex Arifianto and Kalis Stevanus, "Membangun Kerukunan Antarumat Beragama Dan Implikasinya Bagi Misi Kristen," HUPERETESS: Jurnal Teologi Dan Pendidikan Kristen 2, no. 1 (2020): 39-51.

2 Paulus Purwoto, David Eko Setiawan, and Kalis Stevanus, "Kristus Dan Krisna: Upaya Menemukan Point of Contact Dalam Mendialogkan Injil," Jurnal Teologi Praktika 1, no. 2 (2020): 91105, https://doi.org/10.51465/jtp.v1i2.17.

${ }^{3}$ Nasrullah, Agama Dan Konflik Sosial Studi Kerukunan Umat Beragama, Radikalisme Dan Konflik Antarumat Beragama, 147.

${ }^{4}$ Ujang Saefullah, "Dinamika Komunikasi Dalam Mewujudkan Kerukunan Hidup Antarumat Beragama," Jurnal Ilmu Dakwah 5, no. 1 (2011): 411-44, http://journal.uinsgd.ac.id/index.php/jid/article/view/373.

${ }^{5}$ Khotimah, "Dialog Dan Kerukunan Antar Umat Beragama," Jurnal Ushuluddin 17, no. 2 (2011): 214-224, http://ejournal.uin-suska.ac.id/index.php/ushuludin/article/view/693 
kan musyawarah mufakat yang berujung pertikaian baik verbal maupun non verbal, perilaku politik praktis yang menggunakan tema-tema yang dapat membuat keonaran serta ketidakharmonisan, yang mengancam kerukunan antarsesama anak bangsa, khususnya antar umat beragama. ${ }^{6}$ Kondisi yang demikian dapat mengakibatkan tergerusnya kerukunan serta menstimulasi terjadinya masalah intoleransi dan radikalisme, yang berpotensi membawa dampak buruk yang secara tidak langsung dapat mengancam stabilitas keamanan bangsa dan negara serta mengancam kredibilitas dan integritas bangsa. ${ }^{7}$

Fakta berikutnya yang terjadi dalam catatan sejarah adalah terdegradasinya kemajemukan yang sudah dibangun oleh pendiri bangsa ini oleh diskriminasi dan intoleransi. Menurut Denny J. A., adanya praktik dan perilaku diskriminasi yang terjadi saat ini bukan saja terjadi di antara pemeluk kepercayaan atau agama satu dengan pemeluk kepercayaan atau agama yang lain, tetapi dapat juga aterjadi gesekan di antara sesama penganut atau pemeluk kepercayaan atau agama yang sama. ${ }^{8}$ Fakta di lapangan yang di survei oleh yayasan Denny J.A. mencatat, praktik diskriminasi tersebut dalam kurun waktu setelah era reformasi pada tahun 1998 justru lebih meluas dan bervariasi dengan sikap yang penuh otoriter. Pada periode tahun 19982004, terdapat 915 kasus intoleransi yang bermuatan diskriminasi, dan bila diukur dalam satu tahun terjadi 150 persoalan. Sedangkan untuk kasus yang mengarah kepada kekerasan agama, suku, dan keyakinan yang bersifat pribadi terjadi 1.483 kasus kekerasan, atau satu tahun terjadi kurang lebih 210 masalah, yang terjadi dalam tindak kekerasan diskriminasi.

Masalah kerukunan beragama adalah problem yang selalu hangat dan aktual dalam kehidupan masyarakat sosial di bangsa Indonesia ini. Sampai saat ini sejatinya kerusuhan yang ditimbulkan dengan mengatasnamakan SARA masih banyak dilakukan oleh oknum-oknum masyarakat yang melakukan tindakan kekerasan berkaitan dengan intoleransi agama. ${ }^{9}$ Dalam masyarakat sosial dan multikultural di Indonesia, adanya isu mayoritas dan minoritas menjadi bahan provokasi untuk menjadi landasan pertikaian, terlebih konflik dalam masyarakat yang terjadi antar etnis yang kerap muncul di wilayah Indonesia dimunculkan sebagai trigger yang mengakibatkan dampak buruk bagi kerukuann. ${ }^{10}$ Untuk itu dalam kehidupan sosial masyarakat yang pluralis, seharusnya dapat menghargai adanya perbedaan SARA maupun perbedaan dalam segi budaya, adat-istiadat, terlebih lagi perbedaan ajaran atau dogmatika agama, yang sangat rawan memicu timbulnya konflik horizontal dalam masyarakat.

Dalam sisi keberagamaan atau kepercayaan, perilaku maupun tindakan dari in-

${ }^{6}$ angela merici tari Christian, "Toleransi Beragama," Jurnal Ushuluddin, 2019, https://doi.org/10.31219/osf.io/ej5d8.

2.

7 Institut Setara, Dari Radikalisme Menuju Terorisme (Jakarta: Pustaka Masyarakat Setara, 2015),

${ }^{8}$ J A Denny, Menjadi Indonesia Tanpa Diskriminasi (Jakarta: Inspirasi.co, 2014).

${ }^{9}$ Darwis Muhdina, "Kerukunan Umat Beragama Berbasis Kearifan Lokal Di Kota Makassar" (Universitas Islam Negeri Alauddin Makassar, 2014), 5.

${ }^{10}$ Nasrullah, Agama Dan Konflik Sosial Studi Kerukunan Umat Beragama, Radikalisme Dan Konflik Antarumat Beragama, 147. 
toleransi yang memunculkan konflik, dapat dipicu dari personal maupun kelompok yang menonjolkan komunitasnya, hal tersebut bisa saja akibat gesekan dari perbedaan dogmatika, perbedaan pandangan organisasi, paham ajaran agama, ataupun liturgi dalam pelaksanaan peribadatan oleh masing-masing penganut kepercayaan atau agama. ${ }^{11}$ Untuk mewujudkan kehidupan yang tentram dan damai antar maupun intern umat beragama, dalam masyarakat multikultural bukan suatu hal yang mudah. ${ }^{12}$ Olehnya intoleransi telah menjadi salah satu keprihatinan utama dalam kehidupan beragama. ${ }^{13}$ Seperti yang sering terjadi dibangsa Indonesia adanya isu persoalan yang menyangkut tentang agama dapat menyebabkan terjadinya pertikaian verbal maupun non verbal, sehingga berujung perusakan tempat-tempat ibadah. Selaras dengan hal tersebut Jamaludin menyatakan bahwa setelah reformasi pada tahun 1998, konflik horizontal antarumat beragama di negara Indonesia semakin naik intensitasnya dalam masyarakat majemuk. ${ }^{14}$

Berkaitan dengan hal tersebut, Frets dalam tulisan menyatakan bahwa pendidikan yang berbasis pada kebudayaan menjadi hal yang mendesak dan harus diterapkan. ${ }^{15}$ Selanjutnya, ia menawarkan pendidikan toleransi dalam masyarakat multikultural seperti Indonesia, sebaiknya diterapkan di sekolah sebagai peran Pendidikan Agama Kristen dalam menanamkan nilai toleransi. Terlebih saat ini dalam dunia pendidikan formal maupun informal diperhadapkan dengan pesatnya kemajuan ilmu pengetahuan dan teknologi (IPTEK), yang terus berkembang dan berdampak memengaruhi perilaku masyarakat sosial. Senada dengan itu, Saputra menyatakan bahwa "dengan kemajuan IPTEK, manusia dapat memahami terlebih mengenal pribadinya sebagai manusia bersosial dan juga mengenal lingkungan dimana ia tinggal serta dapat berinteraksi secara wajar, sehingga dapat memberikan harapan baru bagi terbentuknya nilai kerukunan dalam dalam masyarakat multikultural. ${ }^{16}$ Paulus Purwoto, Alex, dan Budiyana menyatakan bahwa pendidikan Kristen memiliki landasan dan konsep teologis yang kuat dalam seluruh kitab Perjanjian Baru, di mana pendekatan pendidikan Kristen seharusnya kontekstual sesuai dengan karakter Kristus yang menanamkan kasih dan kerukunan kepada setiap orang dari agama dan kultur manapun. ${ }^{17}$ Sairin juga mengungkapkan bahwa negara Indonesia yang dilahirkan lewat

\footnotetext{
11 Zulfa Jamalie, "Pluralisme, Toleransi, Pendidikan Multikultural Dan Kerukunan Umat Beragama," Jurnal Studi Agama Dan Masyarakat, 2012.

12 Nor Hasan, "KERUKUNAN INTERN UMAT BERAGAMA DI KOTA GERBANG SALAM (Melacak Peran Forum Komunikasi ORMAS Islam [FOKUS] Pamekasan)," NUANSA: Jurnal Penelitian Ilmu Sosial Dan Keagamaan Islam, 2015, https://doi.org/10.19105/nuansa.v12i2.776.

13 Suryaningsi Mila and Solfina Lija Kolambani, "Religious Harmony and Tolerance in Disruption Era: A Study of Local Wisdom in Watu Asa of Central Sumba," Walisongo: Jurnal Penelitian Sosial Keagamaan 28, no. 2 (2020): 171-94.

${ }^{14}$ Nasrullah, Agama Dan Konflik Sosial Studi Kerukunan Umat Beragama, Radikalisme Dan Konflik Antarumat Beragama.

15 Frets Keriapy, "Pendidikan Kristiani Transformatif Berbasis Multikultural Dalam Konteks Indonesia," Regula Fidei: Jurnal Pendidikan Agama Kristen 5, no. 2 (2020): 82-93.

16 (Saputra 2004:37)

17 Yonatan Alex Arifianto Paulus Purwoto, Hardi Budiyana, "Landasan Teologis Pendidikan Kristen Dalam Perjanjian Baru Dan Relevansinya Bagi Pendidikan Kristen Masa Kini," Didaktikos Vol 3, no. 1 (2020): 34-48, https://doi.org/https://doi.org/10.32490/didaktik.v3i1.38.
} 
perjuangan adalah negara kepulauan yang besar, memiliki budaya, dan kemajemukan dalam masyarakat yang heterogen. Bangsa Indonesia juga adalah bangsa yang dianugerahi oleh Allah untuk dirawat atau dipelihara dengan baik, diisi dengan kemajuan yang selaras dengan hukum dan perkembangan zaman. ${ }^{18}$

Berkaitan dengan topik Peran Pendidikan Agama Kristen dalam menanamkan kerukunan di tengah masyarakat multikultural, Yonatan Alex Arifianto mengatakan bahwa kerukunan menjadi tiang pemersatu dalam masyarakat mejemuk. ${ }^{19}$ Untuk itu pendeta dan seluruh jemaat sebagai bagian dari masyarakat multikultural, dapat mengaktualisasikan dan menerapkan nilai-nilai Kristen yang berdasarkan Alkitab bagi toleransi. Karena sikap toleransi yang dilaksanakan oleh orang percaya yang menjadi pembawa terang dan garam bagi sesama juga dapat membawa dampak bagi negara supaya damai dan hidup dalam ketenangan terlebih orang Kristen dapat memuliakan Tuhan. ${ }^{20}$ Fransiskus Irwan Widjaja menegaskan, bahwa pemberitaan Injil harus berorientasi kepada strategi penginjilan dalam konsep Pendidikan Agama Kristen. Penelitian ini memiliki kesamaan dengan beberapa penelitian tersebut, namun juga memiliki kebaruan di mana fokusnya pada peran Pendidikan Agama Kristen dalam menanamkan konsep kerukunan di tengah masyarakat multikultural. Oleh sebab itu, penelitian ini akan meneliti tentang tema tersebut sebagai upaya untuk menanamkan nilai kerukunan di tengah masyarakat yang multikultural.

\section{METODE PENELITIAN}

Penelitian ini merupakan penelitian studi pustaka ${ }^{21}$, dengan pendekatan kualitatif deskriptif. ${ }^{22}$ Peneliti melakukan kajian terhadap berbagai sumber-sumber pustaka lalu menguraikannya dalam sebuah kerangka uraian. Analisis dimulai dari konsep kerukunan dalam berbagai persepektif. Selanjutnya dideskripsikan peran Pendidikan agama Kristen dalam menanamkan kerukunan. Penulis menggunakan Alkitab sebagai sumber utama dan juga dipergunakan buku serta sumber-sumber sekunder lain yang relevan dengan topik sesuai prinsip literature review yang dimaksud oleh Denney. ${ }^{23}$ Penulis juga menggali dari berbagai sumber yang dapat melengkapi artikel ini yang masih dianggap menjadi pendukung artikel ini. Selain itu, penulis menggunakan dan merujuk dari berbagai sumber jurnal dalam mendeskripsikan tujuan penulisan ini yaitu pendidikan agama Kristen dalam menanamkan konsep kerukunan di tengah masyarakat multikultural.

\footnotetext{
18 Weinata Sairin, Visi Gereja Memasuki Milenium Baru (Jakarta: BPK Gunung Mulia, 2002).

${ }^{19}$ Yonatan Alex Arifianto, "Peran Gembala Menanamkan Nilai Kerukunan Dalam Masyarakat Majemuk," Voice Of Hamy Jurnal Teologi Dan Pendidikan Agama Kristen 3, no. 1 (2020): 1-13.

20 Arifianto.

${ }^{21}$ Umrati and Hengki Wijaya, Analisis Data Kualitatif Teori Konsep Dalam Penelitian Pendidikan (Sulawesi Selatan: Sekolah Tinggi Theologia Jaffray, 2020), 12.

22 Umrati and Wijaya, 12.

${ }^{23}$ Andrew S. Denney and Richard Tewksbury, "How to Write a Literature Review," Journal of Criminal Justice Education 24, no. 2 (2013): 218-34, https://doi.org/10.1080/10511253.2012.730617.
} 


\section{HASIL DAN PEMBAHASAN}

Kerukunan dalam masyarakat majemuk, baik antarumat beragama, antarsuku, antargolongan, yang tercermin dalam sikap saling menghargai merupakan corak dari masyarakat Indonesia. Toleransi antarwarga bangsa Indonesia terwujud dalam sikap saling memahami, saling mengerti, saling membuka diri dalam bingkai kerukunan dan persaudaraan sebagai sesama anak bangsa. Kerukunan merupakan sesuatu yang ideal dan didambakan oleh seluruh masyarakat sosial di segala lapisan masyarakat bangsa Indonesia. ${ }^{24}$ Kerukunan di bangsa Indonesia, diikat oleh ideologi Pancasila sebagai sebagai pengikat yang mempersatukan bangsa Indonesia. Konsep Persatuan Indonesia juga juga termaktub dalam semboyan Bhinneka Tunggal Ika yang menjalin tali persaudaraan tanpa memandang perbedaan. Dalam Undang-Undang Dasar 1945 Pasal 28E, ayat satu menyatakan bahwa setiap orang bebas memeluk agama dan beribadat menurut agamanya, ayat dua berbunyi, setiap warga negara berhak atas kebebasan dalam menjalankan ibadah dan iman kepercayaannya, serta memiliki kebebasan dalam menyatakan ide atau gagasan dan sikap sesuai dengan apa yang ada di hati nuraninya.

Terlebih adanya Undang-Undang Dasar 1945 pasal 29 ayat (2) Negara menjamin kemerdekaan dengan kebebasan tiap warga negaranya untuk menganut dan mempercayai agamanya masing-masing dan untuk juga memberi kebebasan dalam melaksanakan peribadatan. Dan mempunyai makna negara berdasarkan atas nilai Ketuhanan Yang Maha Esa. Selain UUD 1945 ada Pasal 22 UU No. 39 Tahun 1999 tentang Hak Asasi Manusia yang menjamin dan menghormati kepercayaan setiap individu dibangsa ini.

Keadaan dan situasi kerukunan dan persatuan negara Indonesia dewasa ini sangat mengkhawatirkan, dengan masih adanya oknum bersikap intoleransi yang menciderai masyarakat majemuk. Sehingga, pemerintah Indonesia bekerja keras membuat aturan untuk menanggulangi konflik yang mana bila dibiarkan akan terus melebar. Oleh karena itu, pemerintah mengeluarkan Surat Keputusan tentang Tri Kerukunan Hidup Beragama, atau dapat disebut dengan istilah "Trilogi Kerukunan". Peraturan tentang Trilogi Kerukunan termaktub dalam Peraturan Bersama menteri Agama dan Menteri dalam Negeri No 9 tahun 2006/ Nomor 8 tahun 2006. ${ }^{25}$ Peraturan tersebut dibuat untuk mengatur masyarakat dalam bersosialisasi serta untuk memberikan keamanan, ketenangan dalam masyarakat majemuk. Namun demikian, masih adanya mispersepsi atau mistafsir dari dogmatika agama oleh pengikut umat beragama maka diperlukan peran pemimpin rohani untuk menjaga dan mengajar penganutnya supaya dapat memiliki sikap menghargai dan menghormati perbedaan

${ }^{24}$ Ibnu Rusydi and Siti Zolehah, "Makna Kerukunan Antar Umat Beragama Dalam Konteks Keislaman Dan Keindonesian," Journal for Islamic Studies, 2018, https://doi.org/10.5281/zenodo.1161580.

${ }^{25}$ Kementerian Dalam Negeri, Menteri Dalam Negeri Republik Indonesia Nomor 38 Tahun 2008 Tentang Penerimaan Dan Pemberian Bantuan Organisasi Kemasyarakatan Dari Dan Kepada Pihak Asing, 2006. 
dan keanekaragaman dari ajaran agama masing-masing ${ }^{26}$, sehingga toleransi dan kesepadanan dari antar intern pemeluk umat beragama, antar pemeluk umat beragama, serta antarumat beragama dengan pemerintah akan terbangun dengan baik, yang dapat memperkokoh persatuan dan kesatuan negara serta memberi dampak positif terhadap stabilitas keamanan nasional. ${ }^{27}$ Oleh karena itu, pemerintah Republik Indonesia mempunyai tugas dan tanggung jawab, serta kewajiban untuk menjaga ketertiban dan menjaga hak dan kewajiban dari personal masyarakat untuk menganut keyakinannya secara personal serta pemerintah juga bertanggung jawab mendidik warganya dengan mendasarkan keamanan bagi kebebasan beragama dengan rasa aman dan tertib, sesuai dengan norma dan sistem hukum yang sah dan yang berlaku di negara ini. 28

\section{Kerukunan dalam Persepektif Alkitab}

Menghargai liturgi maupun dogma agama lain adalah hal yang harus diperkuat dalam kehidupan masyarakat multikultural seperti Indonesia ini. Sebagai pribadi yang beragama dituntut untuk menghormati dan menjaga keyakinan sendiri supaya tidak terombang-ambing oleh iman dan pengajaran agama lainnya. Namun demikian di satu sisi Tuhan juga menginginkan umat-Nya di dunia ini, agar turut ikut berperan dalam tanggung jawab kondisi sosial di sekitar di mana ia berada. Oleh karena itu, Tuhan memberikan suatu tugas kepada orang percaya agar mengasihi sesama seperti juga mengasihi diri sendiri, dan hidup dalam kesaksian yang tulus serta memiliki hati melayani seperti teladan-Nya kepada para muridNya. ${ }^{29}$ Sebagai teladan dalam bersikap toleran, pelayanan yang Yesus kerjakan hari demi hari yang selalu bertemu dan berhubungan dengan orang yang berbeda keyakinan atau aliran baik aliran Yahudi, Saduki maupun Herodian, juga berhadapan dengan para orang-orang Romawi dalam pandangan Helenisme. Yesus juga bertemu dengan orang-orang Samaria. Semua itu tidak membuat-Nya terhasut dan menjadi pribadi yang kejam ketika, mengalami diskriminasi, intimidasi maupun intoleransi. Sikap intoleransi dan kekerasan yang Yesus alami dibuktikan dengan pernyataan yang sungguh mulia ketika Yesus disalib "Yesus berkata: "Ya Bapa, ampunilah mereka, sebab mereka tidak tahu apa yang mereka perbuat (Luk. 23: 34)..$^{30}$

Pengajaran Yesus tentang sikap saling mengasihi adalah bukti yang kuat bagi karakteristik iman Kristen yang harus diaktualisasikan, sehingga diharapkan dapat menjadi berkat dan terang bagi sesama manusia, dilandaskan dan diikat dengan ka-

\footnotetext{
${ }^{26}$ Arifuddin Ismail, “Refleksi Pola Kerukunan Umat Beragama,” Analisa 17, no. 2 (2010): 175, https://doi.org/10.18784/analisa.v17i2.36.

27 Ahmad Sodli, "Kerukunan Umat Beragama Di Provinsi Nusa Tenggara Timur (NTT)," Analisa 16, no. 1 (2009): 64, https://doi.org/10.18784/analisa.v16i1.59.

${ }^{28}$ M. Harudin, Khaidir Khaidir, and H. Rodja Abdul Natsir, "Merawat Keberagaman Menjaga Toleransi Meneropong Peran Forum Kerukunan Umat Beragama Kabupaten Sikka," Academy of Education Journal 11, no. 2 (2020): 168-81, https://doi.org/10.47200/aoej.v11i2.399.

${ }^{29}$ Lenda Dabora Sagala, "Peran Pendidikan Agama Kristen Dalam Menghadapi Perubahan Sosial," Jurnal Simpson: Jurnal Teologi Dan Pendidikan Agama Kristen 1, no. 1 (2017): 48.

30 Yudi Hendrilia, Reni Triposa, and Gloria Gabriel Lumingas, "Menciptakan Kerukunan Umat Beragama Dalam Masyarakat Majemuk Melalui," PNEUMATIKOS: Jurnal Teologi Kependetaan 11, no. 1 (2020): 61-70.
} 
sih, sebagaimana tertulis dalam Kolose 3:14. ${ }^{31}$ Rasul Paulus menasihati jemaat untuk memelihara kesatuan, karena seluruh jemaat adalah satu tubuh, satu Roh, satu pengharapan, satu Tuhan, satu iman, satu baptisan, satu Allah. ${ }^{32}$ Dalam kitab Roma $14: 19$, tertulis bahwa begitu pentingnya kebersamaan dalam kesatuan untuk saling membangun. Bahkan, Paulus menekankan kesatuan supaya tidak ada perpecahan (1Kor. 1:10). ${ }^{33}$ Dalam 1 Petrus 2:17, diperintahkan agar orang percaya wajib menghormati semua orang, baik mereka yang memiliki posisi raja sampai orang biasa, wajib menerima perlakuan yang baik. Warga negara Indonesia yang beragama Kristen tidak dapat melepaskan diri dari tanggung jawab mewujudkan kerukunan umat beragama.

Meneladani sikap mulia Yesus yang telah menunjukkan perbuatan kasih-Nya bagi orang berdosa menjadi acuan dan refleksi yang positif terhadap segala bentuk intimidasi, diskriminasi, maupun intoleransi. Kristus yang telah mati bagi orang percaya dan memperdamiakan manusia dengan Allah, adalah motivasi terbaik dalam membawa pesan kerukunan dalam bingkai kasih Allah dalam masyarakat mejemuk dan multikultural. ${ }^{34}$ Untuk itu orang percaya dituntut meneladani dan mengaktualisasikan ajaran dan tindakan Yesus dalam menjalani kehidupan kekristenan sebagai agen kerukunan bagi sesama. ${ }^{35}$

\section{Kearifan dan pentingnya menjaga kerukunan}

Masyarakat di bangsa ini merupakan komunitas lapisan yang multikultural dengan memiliki nilai-nilai kepercayaan atau agama yang tepat ${ }^{36}$, yang diterapkan di dalam kehidupan sosial, salah satunya saling kerjasama dalam menyelesaikan tugas dan tanggung jawab dengan saling menopang bergotong-royong. Hal ini disebut kearifan lokal (local wisdom). Menurut Frets kearifan lokal yang berkembang di dalam sebuah masyarakat sosial, menjadi jalan untuk menyatakan kasih kepada sesama. Dalam hal ini, ia menyatakan pela gandong di Ambon menjadi sarana untuk mengajarkan kasih kepada sesama. ${ }^{37}$ Pluralisme yang ada dalam lapisan masyarakat sudah sejak lama dan sudah terbiasa sehingga perilaku tersebut dapat menumbuhkan semangat nasionalisme. Kemajemukan yang diterapkan selama ini juga telah menjadi dasar berbangsa dan semboyan negara yaitu "Bhineka Tunggal Ika" (berbeda-beda teta-

\footnotetext{
31 Yonatan Alex Arifianto and Joseph Christ Santo, "Tinjauan Trilogi Kerukunan Umat Beragama Berdasarkan Perspektif Iman Kristen," Angelion 1, no. 1 (2020): 1-14.

32 Joseph Christ Santo, “Makna Kesatuan Gereja Dalam Efesus 4: 1-16," Jurnal Teologi El-Shadday 4, no. 1 (2017): 1-34, http://stt-elshadday.ac.id/e-journal/index.php/el-shadday/article/view/1.

${ }^{33}$ Simon Simon and Yonatan Alex Arifianto, "Kerukunan Umat Beragama Dalam Bingkai Iman Kristen Di Era Disrupsi," JURNAL PENGABDIAN MASYARAKAT DAN INOVASI 1, no. 1 (2021): 35-43.

${ }^{34}$ Hendrilia, Triposa, and Lumingas, "Menciptakan Kerukunan Umat Beragama Dalam Masyarakat Majemuk Melalui."

35 Alfons Renaldo Tampenawas, Erna Ngala, and Maria Taliwuna, "Teladan Tuhan Yesus Menurut Injil Matius Dan Implementasinya Bagi Guru Kristen Masa Kini," EDULEAD: Journal of Christian Education and Leadership 1, no. 2 (2020): 214-31.

${ }^{36}$ Fransiskus Irwan Widjaja, "Pluralitas Dan Tantangan Misi: Kerangka Konseptual Untuk Pendidikan Agama Kristen Dalam Masyarakat Majemuk," Regula Fidei 4, no. 1 (2019), https://doi.org/10.33541/jrfvol1iss1pp115.

37 Frets Keriapy, “Kearifan Lokal Sebagai Jembatan Berteologi Dan Berbudaya,” 2019.
} 
pi tetap satu). ${ }^{38}$ Hal tersebut menjadi ciri khas anak bangsa yang sangat bermanfaat bagi upaya untuk membangun semangat kebangsaan Indonesia. ${ }^{39}$ Toleransi yang ada merupakan suatu kondisi di mana lapisan komunitas multikultural dapat berinteraksi kepada sesamanya, dengan baik di antara sesama anak bangsa. Olehnya para pemimpin rohani hendaknya berada di garda terdepan dalam menjadi teladan sikap toleransi di tengah masyarakat multikultural. Dengan demikian apa yang menjadi tujuan bersama dalam membangun bangsa dapat tercapai yaitu terciptanya masyarakat agamis yang rukun serta toleran. ${ }^{40}$

Kearifan lokal yang dilakukan dalam nilai toleransi menjadi bagian terpenting bagi bangsa dalam mencegah terjadinya konflik, serta dapat membawa masayarakat untuk hidup dalam kebersamaan. Oleh karena itu, membangun kearifan lokal sangat dibutuhkan sebagai upaya untuk menjaga kedamaian bersama, di antaranya dengan memelihara etika sopan santun, budi pekerti, dan menghargai sesama umat beragama yang memiliki bentuk dan cara ibadah yang berlainan. ${ }^{41}$ Toleransi menjadi tujuan dan cita-cita bagi setiap mahkluk sosial, untuk itu dibutuhkan komitmen dan dedikasi sebagai orang percaya dengan memiliki sikap dedikasi untuk menjadi pribadi yang mencerminkan terang dan damai. ${ }^{42}$ Orang Kristen diharapkan mempunyai pengertian yang mendalam terhadap makna kearifan lokal, sehingga mampu menghargai dan memberi sikap saling peduli yang merupakan modal utama bagi keberlangsungan bangsa yang multikultur ini. Kearifan lokal yang termanifestasi kehidupan yang penuh toleransi dalam kehidupan berbangsa dan bernegara, dapat diaplikasikan sebagai spirit perdamaian bagi sesama. ${ }^{43}$ Karena hal itu didasari oleh nilai-nilai universalitas dan kemanusiaan ${ }^{44}$, yang bertujuan untuk menyingkirkan sentimen politik identitas yang dikemas dalam isu-isu bernuansa SARA. Kearifan yang dikerjakan dalam panggilan iman dan kesadaran internal yang berlandasarkan pada sikap toleransi dan menghormati sesama manusia harus didorong dan didasari oleh Kasih. ${ }^{45}$ Hukum kasih yang diajarkan dan diterapkan oleh Yesus bagi murid-muridNya adalah suatu teladan dalam mengasihi Allah dan juga mengasihi manusia ${ }^{46}$, sehingga kasih tersebut membawa orang percaya hidup dalam kearifan yang menjadi berkat bagi sesama. Orang percaya sebagai bagian dari masyarakat multikultural menjadi pelopor untuk

\footnotetext{
${ }^{38}$ Nurmati, “Eksistensi Forum Kerukunan Umat Beragama Di Kabupaten Tana Toraja,” Journal of Chemical Information and Modeling 53, no. 9 (2019): 1689-99.

${ }^{39}$ Siti Makhmudah, "UPAYA MASYARAKAT DALAM MEMBINA KERUKUNAN ANTAR UMAT

BERAGAMA DI KELURAHAN BANGSAL KECAMATAN PESANTREN KOTA KEDIRI," Sekolah Tinggi Agama Islam Nahdlatul Ulama Madiun Vol 4 No 2 (2016).

${ }^{40}$ Arifianto and Santo, "Tinjauan Trilogi Kerukunan Umat Beragama Berdasarkan Perspektif Iman Kristen."

${ }^{41}$ Mawardi, "Reaktualisasi Kerukunan Antar Umat Beragama Dalam Kemajemukan Sosial," Substantia, 2015.

${ }^{42}$ Hendrilia, Triposa, and Lumingas, "Menciptakan Kerukunan Umat Beragama Dalam Masyarakat Majemuk Melalui.”

43 Yonatan Alex Arifianto, "Menumbuhkan Sikap Kerukunan Dalam Persepektif Iman Kristen Sebagai Upaya Deradikalisasi,” Khazanah Theologia 3, no. 2 (2021): 93-104.

${ }^{44}$ Arifinsyah 2013.:65

${ }^{45}$ A. A. Yewangoe, Agama Dan Kerukunan (Jakarta: Gunung Mulia, 2015), 33.

46 "Tafsiran Alkitab Wycliffe,Malang: Gandum Mas," 2001, 38.
} 
hidup arif dan bijaksana dalam mengaktualisaikan toleransi sebagai identitas yang mencerminkan karakter Kristus. Dari sinilah muncul sikap terbiasa dengan kearifan yang dapat memberikan dampak yang baik bagi terjalinnya komunikasi dalam membangun manusia yang utuh dengan hadirnya toleransi bagi persatuan bangsa dan majunya peradaban dunia.

\section{Kepekaan Pendidikan Agama Kristen dalam Menanamkan Kerukunan}

Sejalan dengan sikap dan perilaku manusia yang berubah di berbagai sisi kehidupan bermasyarakat, hidup dalam kesendirian, dan ketertutupan adalah hal yang mustahil dapat dipertahankan sebagai mahkluk sosial. Oleh sebab itu, peran penting Pendidikan Agama Kristen menjadi sarana dan media yang penting untuk menunjang pembentukan spiritualitas murid-murid agar dapat menghadirkan dirinya bermanfaat dalam masyarakat yang heterogen. Dan juga orang Kristen dituntut serta berperan aktif di marketplace di mana ditempatkan oleh Tuhan menjadi berkat di sekitar warga. ${ }^{47}$ Karena kemajemukan dapat ditemukan dalam pendidikan agama Kristen yang terdapat dalam pengajaran iman Kristen bertujuan untuk membantu orang percaya ataupun peserta didik dalam perjumpaannya dengan tradisi Kristiani dan firman Allah sehingga dapat mengambil keputusan berdasarkan isi pengajaran yang Alkitabiah. ${ }^{48}$ Dengan pengembangan kerohanian orang percaya atau peserta didik dalam Pendidikan agama Kristen dapat mengalami perubahan sikap menuju ke kehidupan yang kedewasa rohani. Dari hal itu maka setiap orang percaya dapat memiliki kedewasaan iman $^{49}$, yang dapat diaktualisasikan dalam menjaga kerukunan dan membawa nilai kedamaian bagi sesama.

Peran pendidikan agama Kristen bertujuan agar peserta didik dapat hidup dalam pertobatan serta mengaktualisasi iman Kristen dalam kehidupan sehari-hari sesuai amanat Firman Tuhan. Seperti yang dinyatakan Tuhan Yesus bahwa pertobatanlah yang dapat memberi nilai kekekalan dan menjalani kehidupan sebagai pribadi yang telah ditebus oleh karya Yesus. Olehnya, pendidikan agama Kristen yang baik hendaknya membawa setiap orang percaya kepada pertumbuhan rohani. Pertumbuhan rohani tersebut dapat dilihat dari dua aspek kehidupan, yaitu aspek vertikal, berbicara tentang diperbaharui hubungan seseorang dengan Tuhan yang ditegaskan dan didukung melalui kekuatan firman dan doa; dan juga aspek horizontal yang terlihat dari praktik kehidupan iman seseorang dengan sesama yang memuliakan Tuhan. ${ }^{50}$ Kehidupan yang berpolakan kerjasama antara orang percaya dengan penganut dari agama lain, menghadirkan kedamaian, kasih serta rasa belas kasihan yang termanifestasi dalam kehidupan yang peduli terhadap sesamanya. ${ }^{51}$ Hal tersebut sesuai dengan apa yang ditegaskan Tuhan bahwa Ia menghendaki umat yang percaya atau kepunyaan-Nya berbuat meneladani apa yang Ia lakukan, yaitu sikap peduli ke-

${ }^{47}$ John M. Nainggolan, PAK Dalam Masyarakat Majemuk (Bandung: Bina Media Informasi, 2009),

\footnotetext{
${ }^{48}$ Nainggolan, PAK Dalam Masyarakat Majemuk.

${ }^{49}$ Nainggolan.

50 Sagala, "Peran Pendidikan Agama Kristen Dalam Menghadapi Perubahan Sosial."

51 Sagala.
} 
pada sesama, dan hidup berdampak dengan cara mengambil bagian dalam menyelesaikan persoalan-persoalan atau masalah dalam lingkup sosial. ${ }^{52}$

Pengakuan akan kebebasan dalam mempercayai kepercayaan agamanya merupakan hak dasar yang dijunjung negara. ${ }^{53}$ Oleh karena itu, iman Kristen diharapkan dapat mengaktualisasikan identitasnya sebagai orang percaya serta membawa perubahan dalam dirinya sehingga ada impact bagi penganut kepercayaan atau agama yang lain. ${ }^{54}$ Sejatinya hidup dalam Kerukunan merupakan bagian dari rasa cinta akan bangsanya sebagai tekad bersama untuk maju dalam membangun bangsa. Hal itu perlu didasari rasa nasionalisme terlebih rasa yang berorientasi untuk menghargai, menghormati setiap kepercayaan atau agama, etnis maupun kebudayaan dan adat istiadat yang ada. Bila hal itu di aktualisasikan maka masyarakat secara keseluruhan akan terhindar dari persoalan intoleransi ditengah masyarakat yang multikultural. ${ }^{55}$

\section{Memberikan Edukasi dan menjadi Pelaku Toleransi dalam Masyarakat Majemuk}

Bangsa Indonesia adalah salah satu masyarakat sosial yang majemuk dan multikultural, di mana kehidupan bermasyarakat yang terdiri atas perbedaan namun berakulturasi, dengan memberikan rasa penghormatan terhadap nilai pluralisme sebagai keragaman yang sudah dibangun oleh budaya untuk tetap dilestarikan. Oleh sebab itu diperlukan peran pendidikan agama Kristen yang diharapkan peduli akan perubahan sosial secara umum, melalui kerja sama dengan pribadi pemeluk agama lain. Namun kerja sama yang diinginkan bukannya kerja sama yang bertujuan untuk mengkhianati kepercayaanya, terlebih dapat melunturkan keyakinan dan kepercayaan yang sudah di bangun. ${ }^{56}$ Sebab toleransi antarumat beragama yang terjalin dengan hidup dalam kerukunan menjadi prioritas dan urgensi untuk dijaga dan direalisasikan. ${ }^{57}$ Sikap toleransi menjadi hal yang mutlak dan penting dilakukan ${ }^{58}$, sebab hal tersebut syarat mutlak dan utama adanya persatuan. ${ }^{59}$ Namun sikap over fanatisme terhadap keyakinan sendiri di kalangan pemeluk agama masih sangat tinggi, dan cenderung terlalu kuat, sehingga sangat berdampak disharmoni bagi masyarakat pada umumnya ${ }^{60}$, sehingga dapat mengurangi nilai toleransi dalam masyarakat multikultural.

52 Sagala.

53 Setyo Pamungkas, "Mengkritisi Ruu Kerukunan Umat Beragama: Menjamin Atau Membatasi Kebebasan?," Refleksi Hukum: Jurnal Ilmu Hukum 8, no. 1 (2014): 103-14, https://doi.org/10.24246/jrh.2014.v8.i1.p103-114.

${ }^{54}$ Daeli Dorkas Orieti and Sonny Eli. Zaluchu, "Analisis Fenomenologi Deskriptif Terhadap Panggilan Iman Kristen Untuk Kerukunan Antar Umat Beragama Di Indonesia," JURNAL SUNDERMANN, 2019, https://doi.org/https://doi.org/10.36588/sundermann.vlil.27.

55 Hendrilia, Triposa, and Lumingas, "Menciptakan Kerukunan Umat Beragama Dalam Masyarakat Majemuk Melalui."

${ }^{56}$ Sagala, "Peran Pendidikan Agama Kristen Dalam Menghadapi Perubahan Sosial."

57 Weinata Sairin, "Kerukunan Umat Beragama Pilar Utama Kerukunan Berbangsa: Butir-Butir Pemikiran," 2002.

58 Hasnani Siri and Musyarif, “Caerul Mundzir, Kerukunan Umat Beragama Di Kabupaten,” 2019, 4.

59 (Arifinsyah 2018.:64)

60 Victor YT Tanja, Pluralisme Agama Dan Problem Sosial (Jakarta: Penerbit Pustaka Cidesindo, 1998), 56. 
Pendidikan Kristen dapat melakukan teknik edukasi dengan berbagai cara, di antaranya bekerja sama dengan gereja lokal, sekolah-sekolah Kristen serta lembaga pelayanan Kristen lainnya, untuk mengadakan seminar-seminar yang bertemakan toleransi. Selain itu, dapat bekerja sama dengan para gembala sidang dan para guru agama Kristen untuk menyertakan pengajaran tentang toleransi dalam khotbah mimbar, pendalaman Alkitab di kelompok-kelompok sel, maupun dimasukkan dalam kurikulum Pendidikan Agama Kristen di masing-masing sekolah. Gereja juga dapat mengedukasi warga jemaatnya untuk bertindak bijak dalam bersosial media, menjaga ketentraman dengan menghormati kepercayaan dan peribadatan agama lain. Sebab dengan pendidikan tentang etika dan penekanan terhadap rasa saling menghormati, diharapkan dapat mencerdaskan masyarakat sosial serta memberikan dampak pengaruh hal baik di dalam masyarakat multikultural. ${ }^{61}$

Orang percaya sejatinya wajib membangun sikap empati dan toleransi yang berdasar pada kebenaran alkitabiah, terlebih berada di garis terdepan terkait dengan sikap kebaikan bagi sesama. Oleh karena itu, gereja dan pemimpin umat dapat menjadi teladan terlebih membimbing penuh umat menjadi penggerak pembawa damai di lingkungannya. Untuk itu, setiap orang percaya dapat mengaktualisasikan sikap iman yang didasari kasih di tempat yang nyata, dalam komunitas warga yang terdiri dari kebergaman maupun komunitas yang dibangun melalui platform jejaring yang ada di dunia maya atau media sosial. ${ }^{62}$ Maka pesan komunikasi dalam dialog keberagaman harus dirancang dan diterapkan sebagai dasar kerukunan bersama yang akan membawa impak di segala lini kehidupan bermasyarakat. Kekristenan hendaknya menjadi pelopor dalam membangun karakter dan mental. Sebab di bangsa yang multi-suku dan juga beragam liturgi maupun dogmatika kepercayaannya, maka kerukunan dalam masyarakat multikultural menjadi penting untuk dibangun dan dijaga dalam kehidupan bernegara di Indonesia. ${ }^{63}$ Meskipun peran pendidikan tidak menjamin secara keseluruhan dalam mengatasi semua perilaku dan pergumulan di mayarakat mejemuk dalam perubahan sosial, tetapi setidaknya ada muatan untuk turut memberikan pemahaman bahwa kerukunan perlu dijaga dan dibangun demi keutuhan bangsa.

\section{KESIMPULAN}

Kerukunan dalam masyarakat multikultural harus menjadi prioritas demi kemajuan bangsa dan negara. Terlebih bagi hidup bermasyarakat yang kental dengan perbedaan. Gereja, atau orang percaya diharapkan mampu memberikan aktualisasi dalam menempatkan sikap dan pandangannya. Kesimpulannya, perlu memahami nilai kearifan lokal, dan pentingnya menjaga kerukunan dalam bermasyarakat, agar orang Kristen dapat berkontribusi dalam mengaktualisasikan makna kerukunan, ba-

\footnotetext{
61 Sagala, "Peran Pendidikan Agama Kristen Dalam Menghadapi Perubahan Sosial."

62 Simon and Arifianto, "Kerukunan Umat Beragama Dalam Bingkai Iman Kristen Di Era Disrupsi."

63 Richard G Mayopu, “Jurnalisme Antar Budaya Sebagai Jalan Menuju Toleransi Berbangsa Dan Bernegara," Pax Humana 2, no. 3 Sep (2015): 219-36.
} 
ik kerukunan secara intern maupun antarumat beragama yang berada dalam Negara Kesatuan Republik Indonesia. Kedua, Pendidikan Agama Kristen dapat digunakan sebagai media dalam menanamkan dan mengaktualisasikan nilai kerukunan dalam perspektif Alkitab di tengah masyarakat multikiltural. Ketiga, orang percaya dapat memberikan edukasi dalam komunitas gereja, maupun dalam keluarga dengan berbagai langkah praktis, sehingga diharapkan dapat menjadi pelaku toleransi dalam masyarakat majemuk.

\section{REFERENSI}

A. A. Yewangoe. Agama Dan Kerukunan. Jakarta: Gunung Mulia, 2015.

Arifianto, Yonatan Alex. "Menumbuhkan Sikap Kerukunan Dalam Persepektif Iman Kristen Sebagai Upaya Deradikalisasi.” Khazanah Theologia 3, no. 2 (2021): 93104.

_-_. "Peran Gembala Menanamkan Nilai Kerukunan Dalam Masyarakat Majemuk." Voice Of Hamy Jurnal Teologi Dan Pendidikan Agama Kristen 3, no. 1 (2020): 113.

Arifianto, Yonatan Alex, and Joseph Christ Santo. "Tinjauan Trilogi Kerukunan Umat Beragama Berdasarkan Perspektif Iman Kristen." Angelion 1, no. 1 (2020): 1-14. Arifianto, yonatan Alex, and Kalis Stevanus. "Membangun Kerukunan Antarumat Beragama Dan Implikasinya Bagi Misi Kristen." HUPEERETES: Jurnal Teologi Dan Pendidikan Kristen 2, no. 1 (2020): 39-51.

Arifinsyah. "Saidurrahman,( 2018.) Nalar Kerukunan Merawat Keberagaman Bangsa," n.d.

Christian, angela merici tari. “Toleransi Beragama." Jurnal Ushuluddin, 2019. https://doi.org/10.31219/osf.io/ej5d8.

Denney, Andrew S., and Richard Tewksbury. "How to Write a Literature Review." Journal of Criminal Justice Education 24, no. 2 (2013): 218-34. https://doi.org/10.1080/10511253.2012.730617.

Denny, J A. Menjadi Indonesia Tanpa Diskriminasi. Jakarta: Inspirasi.co, 2014.

Harudin, M., Khaidir Khaidir, and H. Rodja Abdul Natsir. "Merawat Keberagaman Menjaga Toleransi Meneropong Peran Forum Kerukunan Umat Beragama Kabupaten Sikka." Academy of Education Journal 11, no. 2 (2020): 168-81. https://doi.org/10.47200/aoej.v11i2.399.

Hasan, Nor. "KERUKUNAN INTERN UMAT BERAGAMA DI KOTA GERBANG SALAM (Melacak Peran Forum Komunikasi ORMAS Islam [FOKUS] Pamekasan)." NUANSA: Jurnal Penelitian Ilmu Sosial Dan Keagamaan Islam, 2015. https://doi.org/10.19105/nuansa.v12i2.776.

Hendrilia, Yudi, Reni Triposa, and Gloria Gabriel Lumingas. "Menciptakan Kerukunan Umat Beragama Dalam Masyarakat Majemuk Melalui." PNEUMATIKOS: Jurnal Teologi Kependetaan 11, no. 1 (2020): 61-70.

Institut Setara. Dari Radikalisme Menuju Terorisme. Jakarta: Pustaka Masyarakat Setara, 2015.

Ismail, Arifuddin. "Refleksi Pola Kerukunan Umat Beragama." Analisa 17, no. 2 (2010): 175. https://doi.org/10.18784/analisa.v17i2.36.

Jamalie, Zulfa. "Pluralisme, Toleransi, Pendidikan Multikultural Dan Kerukunan Umat Beragama." Jurnal Studi Agama Dan Masyarakat, 2012. 
Kementerian Dalam Negeri. Menteri Dalam Negeri Republik Indonesia Nomor 38 Tahun 2008 Tentang Penerimaan Dan Pemberian Bantuan Organisasi Kemasyarakatan Dari Dan Kepada Pihak Asing, 2006.

Keriapy, Frets. "Kearifan Lokal Sebagai Jembatan Berteologi Dan Berbudaya," 2019.

_-_- "Pendidikan Kristiani Transformatif Berbasis Multikultural Dalam Konteks Indonesia.” Regula Fidei: Jurnal Pendidikan Agama Kristen 5, no. 2 (2020): 8293.

Khotimah. "Dialog Dan Kerukunan Antar Umat Beragama." Jurnal Ushuluddin 17, no. 2 (2011): 214-24. https://doi.org/10.24014/JUSH.V17I2.693.

Makhmudah, Siti. "UPAYA MASYARAKAT DALAM MEMBINA KERUKUNAN ANTAR UMAT BERAGAMA DI KELURAHAN BANGSAL KECAMATAN PESANTREN KOTA KEDIRI." Sekolah Tinggi Agama Islam Nahdlatul Ulama Madiun Vol 4 No 2 (2016).

Mawardi. "Reaktualisasi Kerukunan Antar Umat Beragama Dalam Kemajemukan Sosial." Substantia, 2015.

Mayopu, Richard G. "Jurnalisme Antar Budaya Sebagai Jalan Menuju Toleransi Berbangsa Dan Bernegara." Pax Humana 2, no. 3 Sep (2015): 219-36.

Mila, Suryaningsi, and Solfina Lija Kolambani. "Religious Harmony and Tolerance in Disruption Era: A Study of Local Wisdom in Watu Asa of Central Sumba." Walisongo: Jurnal Penelitian Sosial Keagamaan 28, no. 2 (2020): 171-94.

Muhdina, Darwis. "Kerukunan Umat Beragama Berbasis Kearifan Lokal Di Kota Makassar." Universitas Islam Negeri Alauddin Makassar, 2014.

Nainggolan, John M. PAK Dalam Masyarakat Majemuk. Bandung: Bina Media Informasi, 2009.

Nasrullah, Adon. Agama Dan Konflik Sosial Studi Kerukunan Umat Beragama, Radikalisme Dan Konflik Antarumat Beragama. Bandung: CV.Pustaka Setia, 2015.

Nurmati. "Eksistensi Forum Kerukunan Umat Beragama Di Kabupaten Tana Toraja." Journal of Chemical Information and Modeling 53, no. 9 (2019): 1689-99.

Orieti, Daeli Dorkas, and Sonny Eli. Zaluchu. "Analisis Fenomenologi Deskriptif Terhadap Panggilan Iman Kristen Untuk Kerukunan Antar Umat Beragama Di Indonesia." JURNAL SUNDERMANN, 2019. https://doi.org/https://doi.org/10.36588/sundermann.vlil.27.

Pamungkas, Setyo. "Mengkritisi Ruu Kerukunan Umat Beragama: Menjamin Atau Membatasi Kebebasan?" Refleksi Hukum: Jurnal Ilmu Hukum 8, no. 1 (2014): 103-14. https://doi.org/10.24246/jrh.2014.v8.i1.p103-114.

Paulus Purwoto, Hardi Budiyana, Yonatan Alex Arifianto. "Landasan Teologis Pendidikan Kristen Dalam Perjanjian Baru Dan Relevansinya Bagi Pendidikan Kristen Masa Kini." Didaktikos Vol 3, no. 1 (2020): 34-48. https://doi.org/https://doi.org/10.32490/didaktik.v3i1.38.

Purwoto, Paulus, David Eko Setiawan, and Kalis Stevanus. "Kristus Dan Krisna: Upaya Menemukan Point of Contact Dalam Mendialogkan Injil." Jurnal Teologi Praktika 1, no. 2 (2020): 91-105. https://doi.org/10.51465/jtp.v1i2.17.

Rusydi, Ibnu, and Siti Zolehah. "Makna Kerukunan Antar Umat Beragama Dalam Konteks Keislaman Dan Keindonesian.” Journal for Islamic Studies, 2018. https://doi.org/10.5281/zenodo.1161580.

Saefullah, Ujang. "Dinamika Komunikasi Dalam Mewujudkan Kerukunan Hidup Antarumat Beragama." Jurnal Ilmu Dakwah 5, no. 1 (2011): 411-44. http://journal.uinsgd.ac.id/index.php/jid/article/view/373. 
Sagala, Lenda Dabora. "Peran Pendidikan Agama Kristen Dalam Menghadapi Perubahan Sosial." Jurnal Simpson: Jurnal Teologi Dan Pendidikan Agama Kristen 1, no. 1 (2017): 48.

Sairin, Weinata. "Kerukunan Umat Beragama Pilar Utama Kerukunan Berbangsa: Butir-Butir Pemikiran," 2002.

_-_. Visi Gereja Memasuki Milenium Baru. Jakarta: BPK Gunung Mulia, 2002.

Santo, Joseph Christ. "Makna Kesatuan Gereja Dalam Efesus 4: 1-16." Jurnal Teologi ElShadday 4, no. 1 (2017): 1-34. http://stt-elshadday.ac.id/ejournal/index.php/el-shadday/article/view/1.

Simon, Simon, and Yonatan Alex Arifianto. "Kerukunan Umat Beragama Dalam Bingkai Iman Kristen Di Era Disrupsi." JURNAL PENGABDIAN MASYARAKAT DAN INOVASI 1, no. 1 (2021): 35-43.

Siri, Hasnani, and Musyarif. "Caerul Mundzir, Kerukunan Umat Beragama Di Kabupaten," 2019.

Sodli, Ahmad. "Kerukunan Umat Beragama Di Provinsi Nusa Tenggara Timur (NTT)." Analisa 16, no. 1 (2009): 64. https://doi.org/10.18784/analisa.v16i1.59.

"Tafsiran Alkitab Wycliffe,Malang: Gandum Mas," 2001.

Tampenawas, Alfons Renaldo, Erna Ngala, and Maria Taliwuna. "Teladan Tuhan Yesus Menurut Injil Matius Dan Implementasinya Bagi Guru Kristen Masa Kini." EDULEAD: Journal of Christian Education and Leadership 1, no. 2 (2020): 21431.

Tanja, Victor YT. Pluralisme Agama Dan Problem Sosial. Jakarta: Penerbit Pustaka Cidesindo, 1998.

Umrati, and Hengki Wijaya. Analisis Data Kualitatif Teori Konsep Dalam Penelitian Pendidikan. Sulawesi Selatan: Sekolah Tinggi Theologia Jaffray, 2020.

UT, Saputra. Iman Di Tengah Masyarakat. Bandung: Bina Media Informasi, 2004.

Widjaja, Fransiskus Irwan. "Pluralitas Dan Tantangan Misi: Kerangka Konseptual Untuk Pendidikan Agama Kristen Dalam Masyarakat Majemuk." Regula Fidei 4, no. 1 (2019). https://doi.org/10.33541/jrfvol1iss1pp115. 